\title{
Gender, Migration and Remittances in Ghana
}

\author{
An Overview \\ Esther Ekua Amoako \\ Dept. of Ecotourism and Environment Management \\ University for Development Studies \\ Nyankpala, Ghana \\ Email:ekubee@yahoo.com \\ and \\ Agnes Atia Apusigah \\ Faculty of Education \\ University for Development Studies \\ Tamale Ghana \\ Email:atia.apusigah@gmail.com \\ DOI:http://dx/doi.org/10.4314/gjds.v10i1\&2.2
}

\begin{abstract}
Remittances have become an important source for socio-economic equalizing and leveraging for many households and nations of the developing world. The World Bank had estimated that remittances totaled $\$ 420$ billion in 2009 , of which $\$ 317$ billion went to developing countries. The remittances received become important sources of family (and national) income of many developing economies, representing in some cases a very significant percentage of the GDP of the receiving countries (remittance prices worldwide). Although there is growing interest in the potential contribution of remittances to poverty reduction and community development, reflected in the formulation of policies and programmes to maximize their potential as well as anecdotal evidence on the increasing involvement of women, analysis of the gender dynamics of remittances remains poor. Amid growing evidence of independent female migration, studies in this emerging area of scholarship rarely disaggregate the data and analysis by sex in order to show how men and women participate and/or are affected differently. Using conceptual analysis as a framework that involved concept and content analysis, existing literature and statistical data were examined to establish the gender dimensions of migration and remittances. The analyses show that although men still lead in the migration business, women are becoming a significant part of the crowd and that independent women's migration is on the rise while the women and men who emigrate do so for similar reasons. The analyses also show that the women who participate in the enterprise are vulnerable to various forms of discrimination such as
\end{abstract}


human trafficking, sex harassment and unfair treatment. Hence, there is the need for policies and programmes that tackle women's vulnerability during migration and to engender this emerging area of socio-economic interest of women, families, communities and nations of the developing world who face austere circumstances regarding their development financing.

Keywords: Remittance, Migration, Social Capital, Female Migration, Gender Discrimination

\section{Introduction}

Remittances represent an enormous transfer of resources from the developed to the developing world and in many cases among countries of the South. This has aroused interest among the international community who seek to harness remittances as an important alternative source for development financing. This growing form of transfers has been found to not only complement the financial sources of developing nations but also to be an important form of income for recipient families and households. The remittances to the migrants' families and household have been found to be an important means for uplifting the financial standing and social status of the staying families and households and for promoting local investments and infrastructural development, which boost the development of communities and nations (Oucho, 2010; Adepoju, 2010; Manuh \& Asante, 2005). Above all, migrants' contributions to and initiation of development projects in their communities and countries of origin are helping to cast emigration for work in a positive light instead of the usual lamentation over losses due to brain drain (Manuh, Asante \& Djangmah, 2005; Manuh \& Asante, 2005). Although Manuh and Asante (2005), citing Mkandawire (2002) suggest that the net effect of migration is a drain on the sending destinations, they also recognize the important contributions that the remittances play toward the improvement of the socio-economic conditions of families, communities and states.

In a foreword to the book: At Home in the World? edited by Takyiwaa Manuh(2005:7-8), H.E Arie van der Wiel, an Ambassador of the Royal Netherlands Embassy in Ghana, points out that:

The debate on the relationship between migration and development is longstanding, and many controversial views have been expressed. One of the biggest causes of concern is the brain drain. In relative terms, Africa exports the greatest number of educated and highly educated migrants. This is also a familiar problem in Ghana. However, organizations like the United Nations and the World Bank believe that if effectively managed, international migration can contribute to the growth and prosperity of individuals and their countries of origin and destination.

For the longest time, the emigration of the best of Africa's human resources has been the concern of many due to the persistent loss of specialists such as nurses, doctors, 
engineers, engineers, technocrats and now development practitioners, who have been trained from the national purse and whose contributions are very much-needed for driving development in the sending nations. While well placed, often such lamentations fail to acknowledge the benefits of emigration in the form of the receipts back home; remittances. In academia, many of such emigrants who have become global academic giants were not that mighty when they were home. As migrants, they have had access to the much needed resources, that which pushed many to emigrate in the first place, to develop themselves. As such, they have become first class players in their scholarly fields and especially in the championing of African scholarship and intellectual heritage. Leading scholars in African Literature, Philosophy and Education including Ghanaians such as Kwasi Wiredu and G.J. Sefa Dei as well as Buchi Emecheta and Chukwumeka Eze of Nigeria, among others, became global actors overnight while in migration. In that sense, such academic emigration although has been a drain, has at the same time produced commendable gains. Apart from the gain in expertise and fame, their contributions back home in kind and cash also serve to boost their home academy and economy. In recent decades where out-migration has taken a new dynamism with economic migrants becoming dominant, not only are the gains enormous but the impacts back home are more widespread with multiplier effects (Adepoju, 2010; Abdellatif, 2010).

Twum-Baah (2005) and Adepoju (2005) suggest that the families left behind have become important benefactors of the migration gains. Migrants are said to have become the lifelines of their households and families back home. For many of the economic migrants, remittance is expected any way and refusal or even delay in doing so is queried. In Ghana, where it is common practice for families to contribute toward the migration expenses of emigrants, pay back in cash or kind is expected. Pay back for loans is a must and even beyond that the creditor expects periodic appreciation of their kindness even if it is a loan that has been paid back. For the families who contribute in cash as gift, there is still the expectation that the migrated family member will reach back to them in their time of need or even out of the appreciation of their past generosity. Even for those who support the staying family members of the migrant, back home, such as parents, wives and children, there are expectations that some appreciation will be shown in cash or kind. Hence, whichever way that the matter is looked at, the migrant carries a huge burden to remit their home families, friends and communities.

For persons migrating, remittance serves as an important motivation. Earnings and savings are often repatriated home to assist remaining families especially if the migrant worker is a breadwinner. As Adepoju (2010: 15) notes: "Many African migrants including those residing in developing countries, do not intend to stay indefinitely, and actualize their vision of a permanent return to home by keeping their wives and children in their countries of origin... Migrants thus lead dual lives, socially and economically, by maintaining families, land and other resources at their home-place." Remittances become major means for such maintenance. 
Studies show that remittances form an important driving force for persons migrating from poor to affluent destinations for economic reasons (Oucho, 2010; Ratha 2010; GCIM, 2006). Such economic migrants, especially of the developing countries, seek better employment avenues and enhanced incomes for themselves but also for increasing their ability to cater for the upkeep of families and relations as well as contribute to investments back home. This is especially so for African migrants, whose communalist cultural values oblige them to support their families. Hence, they use remittances as means to support their families and other relations back home. Manuh (2005: 295) shares her field notes of a migrant as follows:

From what I can see, I have virtually transferred back home all that I have acquired since I came here. (...)... First, the money I sent to my brother to start a shop. Well, I know he is a young man and he is not working. Secondly, I know the conditions in Ghana. So I was trying to set him up so he could be doing something profitable and get the means to look after himself etc. With my older brother, the intention was to help him get here and continue his education, but he has still not arrived. As for my mother, when she says she has no money to maintain herself or to eat, then I send her money. (From Manuh (2000), field notes-11/96)

Thus, remittance from migrants becomes an important tool for leveraging poverty back home (Oucho, 2010). As Oucho (2010: 149) explains, "remittances play a positive and effective role in reducing the poverty headcounts and the poverty gap in migrants' countries of origin; they influence poverty reduction, especially in countries of origin with macroeconomic instability, and where households have incomes that re subject to frequent and significant fluctuation." The Global Commission on International Migration (2005) also notes that remittances help to lift recipients out of poverty, increase and diversify household incomes, provide an insurance against risk, enable family members to benefit from educational and training opportunities and provide a source of capital for the establishment of small businesses. Not only do remittances increase the consumption levels of recipient families - so that education and health care are not out of reach - they also, if consciously saved and aggregated, contribute to infrastructure development and investment for increased income in the long term (ISA convention, 2005). For Ratha (2005), remittances augment the recipients' incomes and increase their country's foreign exchange reserves. If remittances are invested, they contribute to output growth; if they are consumed, they generate positive multiplier effects.

Undoubtedly, remittance plays an important role in the development of peoples and countries. Its place as a leveraging and balancing factor raises important socio-economic and equity interests. This is because, as the discussion so far shows, the motivation to leverage is one of equity. Migrants from poor countries seek ways of improving themselves so that they can support their families and relations back home in the poor sending destinations. Their escape from the impoverished conditions back home results in a multiplier effect when they are able to remit their families and support projects at home. 
Even for those not migrating for economic but professional and educational reasons, remittance is still relevant as they tend to care for their families and relations back home.

Increasingly, studies are showing that social: class, race, ethnicity and gender dimensions of migration, are as important as the economic, professional and educational reasons (Adepoju, 2010; Bas-Jones, 2005; Carling, 2005). Yet, the extent to which these have been part of the migration and remittances discourse leaves much to be desired. This paper, which examines migration and remittances from a gender perspective, concentrates on the social dimension for justice and equity reasons. It is particularly interested in examining the extents to and ways by which gender plays out and contributes or not to shaping the emerging discourse on the seemingly booming migration and remittance enterprise, especially in an era when women are increasingly becoming active players. It examines the gender implications of migration and remittance with the view to understand the extents to which women participate in and are affected by the new and emerging area. The paper is in four sections. The first section consists of an overview of remittance and migration in general. The second focuses on gender and migration, the third discusses women and remittances and the final section discusses ways of improving migration and remittances from a gender perspective.

\section{Migration and Remittance}

Oucho (2010: 141) defines remittances as:

...transfers of money, goods and diverse social features, sent or brought by migrants or emigrant groups back to their countries or origin or citizenship. Although the notion of remittances generally conjures up only the monetary aspect, remittances embrace both monetary and non-monetary flows, including social remittances. (...) The North-South Centre of the Council of Europe (2006) defines diaspora's social remittances as ideas, practices, mind-sets, worldviews, values and attitudes, norms of behaviour and social capital(knowledge, experiences and expertise) that the diasporas mediate and, either consciously or unconsciously, transfer from host to home communities.

By the definition above, migration and remittances are closely linked to the development of people and communities. The contributions that migrants make to their home communities and countries go a long way to support their socio-economic progress and national development.

Also, taking from Harvey's (2007) notion of remittances as sums of money or goods sent between individuals over some distance and most commonly understood as transfers between migrants and their places (communities) of origin, it can be said that remittance forms an important part of the development of the local economies that 
benefit from them. For the senders in particular, who remit due to their recognition of the impoverished conditions of the recipients, there is the deliberate attempt to leverage.

Hence, the growing recognition and interest in migration and remittance in development discourses at various levels; globally, regionally and nationally.

\section{The World Stage}

The Global Commission on International Migration (2006) explains that remittances serve to strengthen social ties and networks of responsibility and affection. Indeed, whether one's migration has been supported by family members or not, once in migration, families and relations expect to receive some remittances, be they women or men. They expect that the migrant would be magnanimous in sharing the material benefits of their perceived improved conditions by sending periodic remittances back home. By so doing the receiving parties of family, friends and other relations would also improve their own conditions back home. Through remittances, migrants maintain constant touch with their relations even as they help in their maintenance. Remittances, when substantial, serve to cushion and augment the conditions of the recipients and their families and other relations (Ratha, 2010; Oucho, 2010). Ratha explains that remittances are a critical lifeline for families and entire communities across Africa.

The growing awareness of migratory processes has led to increasing international migration. The UN (2002) estimates that about 192 million people (about 3\% of the world's population) lived and worked outside the country of their birth in 2000, up from 120 million in 1990, and 75 million in 1965. This increasing trend in the human migration over the years has important socio-economic implications for both sending and receiving destinations. An important aspect of the increase in emigration has been the accompanying growth in remittances both in kind and cash. According to World Bank statistics, remittances totaled $\$ 420$ billion in 2009, of which $\$ 317$ billion went to developing countries. Given the current crisis in development financing, vast sums like these have warmed the hearts of various members of the international community.

In the last decade, when the world economy has been battling recession resulting in cutbacks on aid transfers, remittances appear to be gaining grounds, as they have become a significant source for plugging the holes. Multilateral and bilateral development aid has decreased dramatically during the last decade due to the global economic downturn, which has affected the aid dependent development plans and programmes of developing countries. While remittances do not go directly into governments and formal sources for development, the fact that they enter into the economies and mostly through the banking and other financial systems of the recipient families and communities, they have direct and indirect effects on the economies of the recipient countries and their development financing.

The World Bank (2004) found that worldwide remittance flows exceeded total development aid and had become the second largest - and for some countries even 
the largest - financial flow to developing countries after foreign direct investment. Econometric analysis and household surveys suggest that unrecorded flows through informal channels may add 50\% or more to recorded flows. Including these unrecorded flows means that remittances may be larger than foreign direct investment flows, and more than twice as large as official aid received by developing countries (Oucho, 2010; Mohapatra et al., 2006). The World Bank (2010) further estimated that remittance flows to developing countries as a whole would rise further in the next two years, possibly exceeding US\$370.0 billion by 2012. On his part, Ratha (2010) observed that worldwide remittance flows were expected to reach US\$440.0 billion by the end of 2010, up from US $\$ 416.0$ billion in 2009. About three-quarters of such remittance funds, or US $\$ 325.0$ billion, would go to developing countries.

\section{The African Situation}

The movement of people and goods is an age-old practice in Africa. People and goods have moved among and between regions since pre-colonial times. Apart from the intra-African movement, there were active interactions between Africans and their neighbours of the Arabian Peninsula. Islamic scholars and traders have played an active part in the empire building, trade relations and intellectual heritage of West Africa, for instance. Today, northern Africa and parts of eastern Africa have Arab and Asian populations who are African. When the Europeans joined the business they expanded the dimensions. European voyagers, merchants and slavers later became colonizers and settlers in their dealings with the peoples of the continent, sweeping across the continent. While West and Central Africa have been important for forced migration through slave trade, education and evangelization, East and Southern Africa have been the target for forced internal displacements of the Bantu, forced labour of Asian and Middle Eastern peoples and the brutal occupation by Dutch and English settlers.

On the global scale, although sub-Saharan Africa may not be the region with the most migrants, as discriminatory migratory laws tend to disfavor its citizens, remittances have become an important part of the economies of the nations of that region. As a developing region, where the majority of the people are poor; job, higher education and professional development prospects tend to be low, affecting the opportunities for educational and professional excellence and for improving the incomes and quality of lives of impoverished families and communities. Hence, in the case of the latter, whatever is received as transfer from external sources serves as an important boost to the economic standing of not just the individual recipient but also their households, families and communities. Table 1 below shows that over 17 million Africans were in migration in 2005 of which Western Africa carried the highest load of 7,543.092 (44\%) followed by Eastern Africa of 4,516,232 (26\%). Southern Africa was the least sender at 1.380,898 (8\%). 
Table 1: Sub-regional Migration in Africa in 2005

\begin{tabular}{|l|l|l|}
\hline Region & Total & \%Share of Total \\
\hline Africa & $17,068,881$ & 100 \\
\hline Western & $7,543,092$ & 44 \\
\hline Southern & $1,380,898$ & 8 \\
\hline Northern & $1,837,576$ & 11 \\
\hline Middle & $1,791,103$ & 10 \\
\hline Eastern & $4,516,232$ & 26 \\
\hline
\end{tabular}

Source: Adopted from Adepoju, 2010: 56; cited from UNDESA, 2006

Instability in the two subregions, Western and eastern, such as wars, conflicts, political rebellion, religious extremism and their impacts on ordinary citizens, can be said to have contributed to the high carrying loads. These migrants, whether through forced or voluntary means, have tended to be the lifelines of their relatives back home.

Undoubtedly, remittances play a key role in boosting the development efforts of the African continent. In Sub-Saharan Africa, remittances amounted to US\$4.0 billion with an annual growth rate of 5.2\% (IMF, 2002). Remittance flows increased to US $\$ 21.5$ billion by the end of 2010 after a small decrease in 2009 due to the global financial crisis (See Migration, and Remittances Fact Book, 2011). The IMF estimates, showed a decline of 8.3\% in remittances to sub-Saharan Africa in 2009; a situation, which definitely had an impact on the economies of the recipient countries. Nevertheless, remittances have grown to such an extent that in many African countries, they have become among the most important foreign revenue earners. For instance, it was estimated that remittances to Ghana would reach US\$119.0 million in 2010, up from US\$114.0 million the previous year (World Bank, 2010). In absolute dollars, Nigeria was by far the top remittance recipient country in Africa, accounting for US\$10.0 billion in 2010, a slight increase over the previous year of US\$9.6 billion. Other top recipients included Sudan (US\$3.2 billion), Kenya (US $\$ 1.8$ billion), Senegal (US\$1.2 billion), South Africa (US\$1.0 billion), Uganda (US\$0.8 billion), Lesotho (US\$0.5 billion), Ethiopia (US\$387.0 million), Mali (US\$385.0 million), and Togo (US\$302.0 million) as indicated by Ratha (2010). As a share of gross domestic product, the top recipients of remittances in 2009 were Lesotho (25 percent), Togo (10 percent), Cape Verde (9 percent), Guinea-Bissau (9 percent), Senegal (9 percent), Gambia (8 percent), Liberia (6 percent), Sudan (6 percent), Nigeria (6 percent), and Kenya ( 5 percent).

Remittances have grown to such an extent that in many African countries they have become an important source of foreign revenue earnings. Available data extracted from the IFAD's Rural Poverty Portal (2008) and submitted by Oucho (2010) shows that 
remittances form a significant percent of the national GDPs of selected countries. For instance, the rate is 37.9 for Eritrea, the largest and 0.3 for Libya, the smallest. In terms of volume, however, Nigeria leads at USD5,397.0 million; forming 4.7\% of GDP and lowest for Gabon at USD60.0 million at $0.5 \%$ of GDP. The estimates also show that for warthorn and conflict-ridden countries, where productivity had grounded to a near halt, remittances were much significant to the economy. In Liberia, remittances amounted to USD163.0 million, forming $25.8 \%$ of GDP; Sierra Leone: USD168.o million, forming $11.6 \%$ of GDP; Somalia: USD790.0 million, with no GDP rating and Eritrea: USD411.00 million, forming $37.9 \%$ (Oucho, 2010). Hence, for the latter group of countries, where migration was encouraged, remittance contributions were very significant. At the sub-regional level, the data show that Northern Africa leads at USD17,614.0 million, followed by Western at USD10,399.0 million, Eastern at USD5,929.0 million, Central at USD2,690.0 million and Southern at 1,979.0 million1. The volume of remittance has been linked to the extent of migration on the continent. It has been estimated that nearly 22 million Sub-Saharan Africans have left the continent. Africa also has a higher intra-regional migration rate than the rest of the developing world, with three out of four African migrants living in another country in Sub-Saharan Africa (Ratha, 2010).

There is therefore, a pressing need to make it easier and cheaper to send and receive remittances in Africa. The average cost of sending money to Africa is more than 10 percent, the highest among all the regions. The cost of sending money within Africa is even higher, although increasingly, banks are improving and cashing in on their capacities to handle international money transfers through the introduction of Western union and wire transfers such as bank to bank or client payments but also new media such as pay pal and smart cards.

\section{The Ghanaian Connection}

In his exploration of the interrelationships between migration and development, Asante (1995) highlighted the important role played by migrants toward the initiation and funding of development projects in their (rural) localities of origin. He noted that, many of these projects were funded jointly by migrants and non-migrants with migrants normally making larger financial contributions per head with non-migrants often providing considerable labour input. Asante explained that there was a lot of undocumented evidence in Ghana of the construction of second cycle schools, health centers/clinics, community electrification, pipe-borne water supply, markets and feeder roads in rural communities, which had been provided through such combined efforts. Using data from a 1991 Migration Survey, he highlighted the contributions of migration to development by examining urban-to-rural remittance flows. He cited this as one of the avenues through which migration enhanced the welfare of recipient households and communities. Asante also suggested that urban-to-rural remittances sent by ruralto-urban migrants performed a key welfare redistribution function by narrowing the

1 For only three countries; South Africa, Lesotho and Swaziland. 
welfare gap between rural and urban sectors. He further stated that many rural-to-urban migrants were unable to gain employment in the formal sector, and consequently, the informal sector became a haven for the majority of these migrants.

According to Ratha (2010) and Gyimah-Brempong and Asiedu (2008), in Ghana remittances were growing; from US\$31.0 million in 1999 to US\$1.4 billion in 2002. It however fell to US\$114.0 million in 2009 but up again to US\$119.0 million in 2010. They explained that international remittances contributed to improve the living standards of Ghanaian households to the extent that they helped those households to stay out of poverty. They used three measures of income poverty-headcount, poverty gap and the square of poverty gap-as well as the measure of consumption poverty in their analysis. The analysis revealed that international remittances helped households to stay out of poverty and helped to uplift the living conditions of households in the short run. Remittances were also found to help recipient households to acquire higher levels of human or physical capital or some form of business investment. These forms of remittance use may also decrease the poverty of recipient households in the long run. It also confirms Quote's (2006) finding that migrant worker remittances have been a useful source of income to many Ghanaians, particularly in times of economic shocks such as fuel price increase, elimination of agricultural subsidy and weather failure.

The importance of migrant remittances to the economy is evidenced by the proliferation of money transfer institutions in Ghana (both formal and informal) and the rapid growth in the volume of such remittances. Migrant remittances have become a source of external financing at a magnitude estimated to exceed official development assistance in some developing countries (Quartey, 2006). The IFAD (2008) Portal estimates that remittance to Ghana at USD282.0 million formed $1.6 \%$ of its GDP. That is quiet substantial for a developing country whose foreign transfers are largely in the form of loans and grants. According to the Quartey (2006), balance of payments statistics from the Bank of Ghana indicated that the amount of remittances to Ghana exceeded ODA and was a potential force to reckon with particularly considering its growth rate in recent years. It is general knowledge that in Ghana those families with migrant workers, particularly those in developed countries, are able to withstand local income shocks.

Also, in Ghana, migration and remittance flows constitute two of the main forms of linkages between rural and urban sectors (Boakye-Yiadom, 2008). Boakye-Yiadom explains that remittances often flow from migrants to relatives residing in the migrants' country or place of origin. This is especially characteristic of remittances sent by international migrants. While internal migrants (especially, rural-to-urban) have been known to send remittances to relatives in their areas of origin, the flow of remittances from non-migrants to migrants is not uncommon, often taking the form of the transfer of goods, such as foodstuffs. Visits from urban residents to relatives in the rural sector (or visits from rural dwellers to urban residents) are usually occasions for remittance flows in both directions. Urban residents usually give out upkeep money and items, such as canned foods and clothing, while the rural residents typically give out food staples (Tutu, 1995). 
It is also common knowledge that people migrate from resource-poor to resourceendowed areas such as mining, fishing and farming areas. They also migrate from north to south, rural to urban and from villages to towns and cities. In recent years, there has been a growing traffic of migrants especially women and children mainly from northern Ghana to the big cities of southern Ghana especially Accra and Kumasi and even sometimes those of neighboring countries such as Ouagadougou in Burkina Faso, Abidjan in Cote d'Ivoire and Lome in Togo. This growing trend is also fraught with illegalities such as human trafficking, child labour and forced labour (Apusigah and Adama-Mohammed, 2005). There is also evidence of prostitution, organized crime, forced marriage and drug trafficking. Tutu (1995), drawing from the 1991 Migration Research Study, asserts that the major forms of migration are rural-rural, rural-urban, and urban-rural, in that order. Ghanaians also migrate to other parts of Africa and the whole world as will be shown later in this paper.

According to Boakye-Yiadom (2008), the provision of basic amenities and infrastructure is skewed toward the urban sector, making rural-to-urban migration an expected objective of many rural residents. These are mainly the push-pull factors that promote migration (Lee, 1966). It has been argued that in many cases, migration is employed as a livelihood support mechanism for diversifying income and insuring the entire household (including the migrants) against risks and uncertainty. This view of migration often places remittance flows within the context of a migration-remittance strategy (Boakye-Yiadom, 2008). Thus, remittances augment the recipient individuals' incomes and increase the recipient country's foreign exchange reserves (Ratha, 2005).

In Remittances and Poverty in Ghana, Gyimah-Brempong and Asiedu (2008), discuss the impact remittances have on Ghanaian households. They argue that: "Remittance must be seen as a contingent flow from a joint family decision to send its young children abroad in exchange for financial flow from the emigrant to smoothen the family consumption." They observe that international remittances improve the living standards of Ghanaian households to the extent that they help those households to stay out of poverty. Indeed, there are entire communities and regions in Ghana, where it is common knowledge that migration is a preoccupation. Communities such as Kumasi, Konongo, Odumasi, Nkwatia, Sunyani, Aburi, Berekum and Chiraa and regions such as Ashanti, Brong-Ahafo and Eastern are well known for their history of migration. These communities are well-known for their flashy cars and luxurious houses, owned by non-residents. The fact that remittances are so large, come in foreign currency, and go directly to households and communities, means that these transfers have a significant impact on poverty reduction in the form of funding for housing and education, basic essentials, and even business investments.

\section{Gender and Migration}

Migration has always been gendered in a male-dominated context where the man and patriarch, defined as provider, steps out of the home to find food for the family. As alluded to above, forced migrations under British colonialism, whether for enlistment 
into the West African Frontier Force or mining, cocoa or construction (railways and highways) industries, had targeted men. It was men who were considered the workers and not women. In the process, the men were separated from their families and often placed in "concentration camps" as public sector workers leaving behind their ageing parents, wives, children and other relations. Apart from cutting off their social support, the impoverished conditions into which these men were forced to live, did not only affect them emotionally and socially in their work places but also their family and relations back home. Their wives and children had to take on complete roles as care givers even as they remained separated from the husbands and fathers. In cases where it was possible for wives to visit their husbands on temporary bases or even migrate to join their husbands, they did so only as secondary or dependent migrants.

Beyond the forced migrations, even when people have moved freely, the patriarchal dynamic still define the form and nature of migration; pre-colonial, colonial or postcolonial times. Men, as titled providers, better educated, preferred employees and with the legitimacy of entry to the public space did so resulting in their dominant place in the migration enterprise. In recent time, however, the trend is changing as increasingly women are migrating on their own and/or forced to do for reasons that were hitherto considered male. While male migration is still higher compared to women, it is also the case that some men are also staying back home with children and families while their wives are in migration.

Sub-regional data from UNDESA, cited by Adepoju (2010), shows that female migration remained significant although lower than male migration. Table 2 below depicts Western Africa as the leader in sending out migrants followed by Eastern Africa. More importantly in both cases the number of males is still higher than that of females. The data for the Africa region also shows that more males compared to females were in migration in 2005 . Noteworthy, is that the region has been engulfed (still are) in major conflicts or postconflict reconstruction during the period, when refugee migration was encouraged and especially for women and children.

Table 2: Estimated Migrant Stock, Africa and sub-region by Gender, 2005

\begin{tabular}{|l|l|l|l|}
\hline Region & Female & Male & Total \\
\hline Africa & $8,091,923(47 \%)$ & $8,976,958(53 \%)$ & $17,068,881(100 \%)$ \\
\hline Western & $3,694,522(49 \%)$ & $3,848,570(51 \%)$ & $7,543,092(100 \%)$ \\
\hline Southern & $585,121(42 \%)$ & $795,777(58 \%)$ & $1,380,898(100 \%)$ \\
\hline Northern & $801,190(44 \%)$ & $1,036,386(56 \%)$ & $1,837,576(100 \%)$ \\
\hline Middle & $828,907(46 \%)$ & $962,196(54 \%)$ & $1,791,103(100 \%)$ \\
\hline Eastern & $2,182,183(48 \%)$ & $2,334,049(52 \%)$ & $4,516,232(100 \%)$ \\
\hline
\end{tabular}

Source: Adopted from Adepoju (2010: 56) 
Adepoju (2010: 55) attributes the current trend of growing female migration to "the changing roles of women in fulfilling their own economic needs, rather than simply depending on their spouses or moving to join their spouses (Adepoju, 2004; IOM, 2003)." The widespread nature of the kayayee ${ }^{2}$ phenomenon in Ghana is a clear testimony. As will be shown in later sections both married and unmarried women are moving for economic reasons but also for education and more. This new dynamic also means that we cannot afford to view and treat migration using the male-centered lens of the past.

Data on Ghana departures for 2003 for the period January to March from the Ghana Immigration Service shows an interesting gender trend. It shows that while males dominated in four of the categories; namely, professional/technical, management/ business/financial operations, administration/secretarial and elementary occupation/ agriculture/fishing categories, females dominated in three, namely, the personal services/skilled trades, sales/customer service and production transport/equipment operation categories. Note also that there a close match between males and females in the administrative/secretarial categories at 9.7 for males and 8.6 for females. Conspicuously mysterious is the fact that, while the inadequately described or inactive occupational status of female was 33.4 that for men was 29.5. See Table 3 below.

Table 3: Ghana Departures, 2003

\begin{tabular}{|l|l|l|l|}
\hline Occupation & Total & Male & Female \\
\hline Professional/Technical & 24.1 & 29.3 & 15.0 \\
\hline Management/Business/Financial Operations & 6.0 & 7.5 & 3.5 \\
\hline Administrative/Secretarial & 9.3 & 9.7 & 8.6 \\
\hline Personal Services/Skilled Trades & 6.5 & 3.9 & 11.1 \\
\hline Sales/Customer Service & 15.4 & 14.0 & 17.8 \\
\hline Elementary Occupation/Agriculture/Fishing & 3.1 & 4.3 & 1.0 \\
\hline Construction & - & - & - \\
\hline Production Transport/Equipment Operation & 4.7 & 1.9 & 9.6 \\
\hline Inadequately Described/Inactive & 30.799 & 29.5 & 33.4 \\
\hline
\end{tabular}

Source: Manu, 2005: 72

Gender issues in migration are increasingly becoming an interesting part of migration studies due to emerging evidence on the differentiated experiences of women and men in migration or intending to migrate. Interesting dynamics in the sex and reasons for

2 Women and girls who move from northern to southern Ghana to work as head porters. 
migrating as well as the experiences of migrants are compelling scholars to pay attend to gender analysis of migration data. For instance, shifts in the sex characteristics of migrants with an increasing female component present an interesting dynamic in migration studies that could be termed the feminization of migration. Studies on migration, locally (Ghana) and globally, show that women are increasingly becoming a significant part of the migrant crowd. Women from all over the world are moving on their own or with families from home destinations to new destinations for various purposes including the economic. More importantly, more and more women are migrating on their own instead of being accompanied by family or space. Women are increasingly becoming primary migrants rather than secondary migrants who accompany other family members in migrant or migrating. The picture is not different for Africa, where diverse factors and forces such as war and conflict, economic crisis and widespread poverty, are pushing people out of their families, communities and countries. Table 4 below, is an estimate from UNDESA (2006). It shows a growing trend of female participation in migration.

Table 4: African Female Migration (1960-2005) (in thousands)

\begin{tabular}{|c|c|c|}
\hline Year & No. of Female Migrants & Period Change \\
\hline 1960 & 3859 & o=base \\
\hline 1965 & 3992 & 133 \\
\hline 1970 & 4241 & 249 \\
\hline 1975 & 4739 & 498 \\
\hline 1980 & 6217 & 1,478 \\
\hline 1985 & 6410 & 193 \\
\hline 1990 & 7505 & 1,095 \\
\hline 1995 & 8357 & 852 \\
\hline 2000 & 7785 & -572 \\
\hline 2005 & 8092 & 307 \\
\hline
\end{tabular}

Source: Adopted from Adepoju (2010:55)

Studies show that women like men are migrating for economic reasons (Adepoju, 2010; Anarfi, Kwankye \& Ahiadeke, 2005). The old tradition where women migrated for social and conjugal reasons, largely to join their spouses, is also changing. From the traditional trend where women migrated to join their spouses, studies are finding that women are also migrating on their own for socio-economic purposes. Hence, women are also using migration as a way of improving their living conditions. In a study on migration in the health sector of Ghana, Anarfi, Kwankye and Ahiadeke (2005), drawing from a study by 
Buchan and Dovlo (2004), reported on the number of nurses who had made verification on opportunities to migrant. See Table 5 below.

Table 5: Nurses Seeking Qualification Verification to Migrate

\begin{tabular}{|l|l|l|l|l|l|l|l|}
\hline Country & $\mathbf{1 9 9 8}$ & $\mathbf{1 9 9 9}$ & $\mathbf{2 0 0 0}$ & $\mathbf{2 0 0 1}$ & $\mathbf{2 0 0 2}$ & $\mathbf{2 0 0 3}$ & Total \\
\hline USA & 50 & 42 & 44 & 129 & 81 & 80 & 426 \\
\hline UK & 97 & 265 & 646 & 738 & 405 & 317 & 2,468 \\
\hline Canada & 12 & 13 & 26 & 46 & 33 & 10 & 140 \\
\hline $\begin{array}{l}\text { South } \\
\text { Africa }\end{array}$ & 9 & 4 & 3 & 2 & 6 & - & 24 \\
\hline Others & 4 & 4 & 8 & 8 & 5 & - & 29 \\
\hline Total & 172 & 328 & 727 & 923 & 530 & 407 & 3,087 \\
\hline
\end{tabular}

Source: Manu (2005:232)

However, in terms of employment rates, men are ahead of women. Table 6 below shows that of Ghanaians 15 years and above in migration, 191,019 (100\%) were employed with men forming $66 \%$ while female formed $34 \%$. Of those unemployed the gap is closer with male forming $58 \%$ while female form $42 \%$.

Table 6: Emigration of Ghanaians 15 years and older by sex and economic activity

\begin{tabular}{|l|l|l|l|}
\hline Economy Activity & Male & Female & Total \\
\hline Employed & $125,637(66 \%)$ & $65,382(34 \%)$ & $191,019(100 \%)$ \\
\hline Unemployed & $8,828(58 \%)$ & $6,517(42 \%)$ & $15,345(100 \%)$ \\
\hline Student & $20,863(59 \%)$ & $14,321(41 \%)$ & $35,184(100 \%)$ \\
\hline Other & $4,948(55 \%)$ & $4,127(45 \%)$ & $9,075(100 \%)$ \\
\hline
\end{tabular}

Source: Adapted from GSS (2012). PHC 2010 Report, pg. 39

Above all, there is also evidence that women are migrating for socio-cultural reasons. They are migrating in order to escape from unfavourable gender relations or bad conjugal relations. The former entails a situation where women had tended to migrate because they have been limited by the existing unequal gender regimes which limit their opportunities and benefits of development. In cultures where unequal social relations and gender hierarchies limit women's opportunities to education, access to socio-economic resources and place women in subjugated positions, some migration by women has been propelled by the need to seek for and live in relatively gender equitable societies where they perceive 
to have better prospects and possibilities to explore existing opportunities in education, work and wealth, as well as for enhancing their welfare, dignity and status. Women have also tended to migrate in order to escape from violent relationships such as intimate partner violence or domestic violence. Others have done so in order to escape harmful cultural practices such as female genital mutilation, forced marriage, widow inheritance and polygamous relationships.

Moving internally within countries, or internationally between countries (from sending to receiving country) may be a move for the short or long term or for economic, political or social reasons. Migration may also be regular (conforming to legal requirements) or irregular. The migrant may have varying degrees of choice over whether or not they move - the decision may be somewhere between "forced" and "voluntary" (Harvey, 2007). Criminal rings and gangs often explore irregular routes to traffic women and children, who they hold illegally put to criminal employment. Women in irregular and forced migration often find themselves living under sub-human and in-dignifying conditions as househelps, sex workers and underground/sweatshop workers. Under such conditions, they have tended to earn minimal incomes and often with no welfare benefits. In some cases, women and girls are pimped by madams or bosses who benefit from their street earnings even as they violate their bodies and rights.

There is overwhelming evidence that migration can provide new opportunities for improving women's lives and changing oppressive gender relations. Even displacement as a result of conflict can lead to shifts in gendered roles and responsibilities to women's benefit. Education is one area that has been found to offer opportunities for women more than men migrants. Yet, in a study on returned Ghanaian migrants, Anarfi, Kwankye and Ahiadeke (2005) drawing data from a 2001 Transrede Study revealed the following as presented in Table 7.

Table 7: Percentage Distribution of Return Migrants by Education and Sex

\begin{tabular}{|c|c|c|c|c|c|c|c|c|c|c|c|c|}
\hline \multirow{2}{*}{$\begin{array}{l}\text { Level of } \\
\text { Education }\end{array}$} & \multicolumn{6}{|c|}{$\begin{array}{l}\text { Unskilled Return Migrants in Ghana } \\
\text { Abroad }\end{array}$} & \multicolumn{6}{|c|}{$\begin{array}{l}\text { Skilled Return Migrants in Ghana } \\
\text { Abroad }\end{array}$} \\
\hline & M & $\mathrm{F}$ & $\mathrm{T}$ & M & $\mathrm{F}$ & $\mathrm{T}$ & M & $\mathrm{F}$ & $\mathrm{T}$ & $\mathrm{M}$ & $\mathrm{F}$ & $\mathrm{T}$ \\
\hline No Education & 0.0 & 2.3 & 0.6 & 31.2 & 44.2 & 34.9 & 0.0 & 0.0 & 0.0 & 0.0 & 0.0 & 0.0 \\
\hline Primary & 10.1 & $23 \cdot 3$ & 13.8 & 0.0 & 0.0 & 0.0 & 0.8 & 6.9 & 1.9 & 0.0 & 0.0 & 0.0 \\
\hline Vocational & 0.0 & 0.0 & 0.0 & 14.7 & $9 \cdot 3$ & 13.2 & 1.6 & 0.0 & 1.3 & 0.0 & 0.0 & 0.0 \\
\hline Secondary & 35.8 & 32.6 & 34.9 & 0.0 & 0.0 & 0.0 & 31.7 & 27.7 & 30.9 & 0.0 & 0.0 & 0.0 \\
\hline Tertiary & 25.7 & 27.9 & 26.3 & 0.0 & 0.0 & 0.0 & 5.7 & 3.4 & $5 \cdot 3$ & 13.9 & 23.1 & $15 \cdot 5$ \\
\hline University & 28.4 & 13.9 & $24 \cdot 3$ & 30.3 & 23.3 & 28.3 & 54.5 & 58.6 & $55 \cdot 3$ & 78.7 & 61.5 & 75.7 \\
\hline
\end{tabular}




\begin{tabular}{|l|l|l|l|l|l|l|l|l|l|l|l|l|}
\hline Language & 0.0 & 0.0 & 0.0 & 8.2 & 4.6 & 7.2 & 0.0 & 0.0 & 0.0 & 0.0 & 0.0 & 0.0 \\
\hline Other & 0.0 & 0.0 & 0.0 & 15.6 & 18.6 & 16.4 & 5.7 & 3.4 & 5.3 & 7.4 & 15.4 & 8.8 \\
\hline Total & 100 & 100 & 100 & 100 & 100 & 100 & 100 & 100 & 100 & 100 & 100 & 100 \\
\hline
\end{tabular}

Source: Anarfi, Kwankye and Ahiadeke (2005: 209)

Table 7 above shows that more male than female unskilled return migrants have education in Ghana and in Abroad, indicative of females lower chances of getting a job compared to male. It also suggests that more females than male even in this unskilled category had no education and as such more females than males were likely to be confined to minimum wage low paying jobs with all their constrictions such as poor welfare benefit, employment insecurity and vulnerability to exploitation and violence. This situation tends to further entrench traditional gender roles and perpetuate inequality and violence against women. Also, from the same data set, in the skilled return migrant category, although both males and females pursued university/tertiary education and were in the majority, what was interesting was that more female skilled returnees, at $58.6 \%$, had university education in Ghana before migrating compared to males at $54.7 \%$. More striking however is that, for those who pursued university education abroad, the gap was wider with females at $61.5 \%$ while males were at $78.7 \%$; that is 17.2 percentage point difference.

For the return migrants, another interesting trend was the marital status of males and females. Table 8 below shows that majority of the return migrants, whether skilled or unskilled were married/cohabiting, however there were more females than males in the single and divorced categories. This supports studies that show that women are migrating independently in recent time (Adepoju, 2010).

Table 8: Marital Status of Return Migrants by skill and sex

\begin{tabular}{|l|l|l|l|l|l|l|}
\hline \multirow{2}{*}{ Marital Status } & \multicolumn{3}{|l|}{ Skilled Return Migrants } & \multicolumn{3}{l|}{ Unskilled Return Migrants } \\
\cline { 2 - 7 } & Male & Female & Total & Male & Female & Total \\
\hline Single & 6.5 & 20.7 & 9.2 & 10.1 & 14.0 & 11.2 \\
\hline Married/Cohabitation & 87.1 & 58.6 & 81.6 & 78.0 & 53.5 & 71.0 \\
\hline Separated & 0.8 & 0.0 & 0.7 & 0.9 & 9.3 & 3.3 \\
\hline Divorced & 2.4 & 20.7 & 5.9 & 6.4 & 11.6 & 7.9 \\
\hline Widowed & 2.4 & 0.0 & 1.9 & 4.6 & 11.6 & 6.6 \\
\hline Not Stated & 0.8 & 0.0 & 0.7 & 0.0 & 0.0 & 0.0 \\
\hline Total\% & 100 & 100 & 100 & 100 & 100 & 100 \\
\hline N & 123 & 29 & 152 & 109 & 43 & 152 \\
\hline
\end{tabular}

Source: Anarfi, Kwankye \& Ahiadeke (2005:208) 
In contrast, Adepoju (2010:17) explains that:

Forced to do more with less, and propelled by the economic crisis, families are developing a variety of survival strategies, including autonomous female migration. Anecdotal evidence reveals an increase in migration by women, who had traditional remained at home, while men moved around in search of paid work. The improved access of females to education and training opportunities has enhanced their employability locally and across national border. In many parts of the region, the emergence of migrant females as bread-winners puts pressure on traditional gender roles within families. The gendered division of family labour has been upset by the loss of male employment through urban job retrenchment and structural adjustment, forcing women to seek additional income-generating activities to support the family. Such family survival strategies in the face of harsh domestic economic conditions, and changing gender roles, create new challenges for the research and public policy.

For Adepoju, improvements in the fortunes of women, especially in education and training has also improved their marketability. Indeed as Table 7 above shows, many women had tertiary/university education or pursued it while abroad. This was important for them to improve their chances of entering the job market and increasing their incomes. Also, though the analysis this far suggests that migration is a coping, balancing and empowerment mechanism, it would appear from Adepoju's allusions that even in this case women are trapped in the old traditions of an instrumentally gendered use, which could be detrimental. For those families who send out their females into migration, it is not necessarily out of choice or concern but out of the need to derive value from women, probably as a last resort.

Studies also show that women, compared to men, tend to move for shorter distances. Women migrants are more likely to migrate internally or just across borders than migrant men. The north-south migration trend in Ghana is a clear case of not just the tendency for women to migrant for shorter distances but also the increasing gendered nature of that form of migration. Although not a new phenomenon, dating back to pre-colonial times, the interference of the imperial structure started a gendering process that has been worsened by recent challenging socio-economic conditions. In the past, pre-colonial times, trade in animals, crafts, salt and kola, involved long distance travels of traders from northern to southern Ghana and destinations elsewhere on foot where they stayed for extended periods and sold their wares. When sold out such traders bought and transported wares from the south back to the north. The risks and drudgery of trading at that time, resulted in the male-domination of the area. The maleness of migration was intensified when northern men were forced out or compelled by economic circumstances or the colonial machinery to serve in the West African Frontier Force or work in the mines or on cocoa farms of southern Ghana as noted above. What happened during this era of 
forced migration was that families were split apart and some even lost their members as they were never able to reconnect. In many cases, however, children and women especially wives were compelled to migrate to join their migrant relations or live without them and fend for themselves.

At the same time, women migrants, especially if they were irregular migrants, face stigma and discrimination at every stage of the migratory cycle. Before departure, women could be faced with gender-biased procedures and extortions by corrupt officials. In fact, gender discrimination, poverty and violence, can provide the impetus for women to migrate or enable women to be trafficked in the first place. In transit and at their destinations, women can be faced with verbal, physical and sexual abuse, poor housing and encampments, sex-segregated labour markets, low wages, long working hours, insecure contracts and precarious legal status. In addition, upon return to the source country they may be faced with stigmatization, broken homes, illness, and poverty (Apusigah \& AdamaMohammed, 2005).

In recent years, attempts to engender international migration flows have led to various responses to stem factors such as discriminatory legislation, gender-selective demand for foreign labour, and unequal gender relations in countries of origin. These factors have often worked together to increase the share of women in emigration flows. As a result, the growing feminization of migration has been recognized as an interesting trend at the global level (Castles and Miller, 2003). According to Carling (2005), women today make up nearly half of all international migrants. One reason is that family and refugee migration, in which women usually outnumber men, have grown in importance vis-à-vis labour migration. Another reason is that more women migrate independently for work (Carling, 2005). Alongside women's increasing participation in conventional labour migration, specifically female forms of migration, have emerged. These include the commercialized migration of domestic workers (sometimes labeled 'the maid trade'), the migration of independent women professionals, trafficking of women in the sex industry, and the organized migration of women for marriage (sometimes labeled 'mail-order brides'). These offer opportunities but also serve as fertile grounds for violence against women and/or criminal exploitation.

Most women move voluntarily, but women and girls are also part of the flow of forced migrants who have fled conflict, persecution, environmental degradation, natural disasters and other situations that affect their habitat, livelihood and security. Traditionally, women had migrated officially as dependent family members of other migrants or future spouses of men in another country (Global Commission on International Migration, 2005). They have also migrated as transnational care givers, mostly for migrant family members. But in recent time, transnational care giving has become a business with women recruited by agencies to live and work as au pairs or nannies. 
Locally, earning money to buy the goods needed to make a good marriage can be a motivator of migration for both boys and girls migrating from early to late teenage years. Kayayee, the phenomenon of female migration for odd jobs in cities such as carrying head loads of goods for a fee, is one outcome of such socio-culturally motivated migrations (Apusigah and Adama-Mohammed, 2005). While boys have more opportunities for employment and migration, parents are also becoming accepting of the migration of girls because girls traditionally move to their husband's family upon marriage, so will leave anyway. One father said of his daughter's migration, "I approved because she is a girl and so has to leave" (Hashim, 2005). This may be one of the reasons why many young girls migrate from the northern Ghana to southern Ghana to live and work as kayayee.

In Ghana, wars and conflicts in northern Ghana have displaced several families and pushed women and girls out of their homes and regions. Along the main highway from Accra to Tamale and especially in the Brong-Ahafo Region, one finds several foodstuff sale points that are run by women migrants of northern origins. Several of such points have been mounted by Basare and Konkomba women, whose ethnic groups had been embroiled in inter and intra ethnic conflicts. This twist of events is a new experience which the migrant women have to contend with and of which they must find coping strategies in their new destinations. Without the social capitals available to them in their new destinations such as that afforded by families and communities of origin, the women have to devise new strategies of coping.

Furthermore, while there has been no major change in the percentage of women and men moving internationally, overall, there have been changes in patterns of migration - with more women migrating independently and as main income-earners instead of following male relatives (Martin, 2005). There have also been changes in patterns between different regions and countries. According to GSS (2000), 52 percent of Ghana's adult populations were migrants, with the corresponding percentages for men and women being roughly the same (51.4 and 52.2, respectively), confirming the fact of an increase in women migrants. However, the 2010 PHC data shows a decline with men at $66.8 \%$ and women at $33.2 \%$ indicating a ratio of 2:1 as depicted in Table 9 below. Table 9 also shows that the largest number of Ghanaian emigrants live in countries outside the ECOWAS sub-region at $10.4 \%$ followed by Cote d'Ivoire at $7.8 \%$. Cote d'Ivoire also hosts as nearly many women as men migrants. Nearness could be a factor

Table 9: Emigration of Ghanaians 15years and Older by sex and destination in Africa

\begin{tabular}{|l|l|l|l|}
\hline Destination & Male & Female & Total \\
\hline Nigeria & 11,803 & 5,289 & $17,092(6.8 \%)$ \\
\hline Liberia & 2,520 & 1,149 & $3,669(1.5 \%)$ \\
\hline Sierra Leone & 1,003 & 553 & $1,556(0.6 \%)$ \\
\hline
\end{tabular}




\begin{tabular}{|l|l|l|l|}
\hline Destination & Male & Female & Total \\
\hline Gambia & 2,654 & 1,687 & $4,341(1.7 \%)$ \\
\hline Togo & 3,904 & 3,921 & $7,825(3.1 \%)$ \\
\hline Burkina Faso & 1,556 & 820 & $2,376(0.9 \%)$ \\
\hline Cote d'lvoire & 9,948 & 9,535 & $19,483(7.8 \%)$ \\
\hline Other ECOWAS States & 5,596 & 1,981 & $7,577(3.0 \%)$ \\
\hline Africa, other than ECOWAS & 21,165 & 4,945 & $26,110(10.4 \%)$ \\
\hline All Africa & $60,149(66.8 \%)$ & $29,880(33.2 \%)$ & $90,029(100 \%)$ \\
\hline
\end{tabular}

Source: Adapted from GSS, 2012 PHC Report: 38

In Table 10 below one finds similar male-female dynamic of about 2:1; 160,276 (64\%) male and 90,347 (36\%) female. It also shows that Europe has the highest concentration of Ghanaian emigrants followed by those in Africa. Noteworthy is that the gap between Africa and Europe is very close at 1.8 percentage points difference.

Table 10: Emigration of Ghanaian 15 years and above round the Globe by sex and region

\begin{tabular}{|l|l|l|l|}
\hline Destination & Male & Female & Total \\
\hline Africa & 60,149 & 29,880 & $90,029(35.9 \%)$ \\
\hline Europe & 59,369 & 35,102 & $94,471(37.7 \%)$ \\
\hline Americas & 35,496 & 23,610 & $59,106(23.6 \%)$ \\
\hline Asia & 4,336 & 1,336 & $5,672(2.3 \%)$ \\
\hline Oceania & 926 & 419 & $1,345(0.5 \%)$ \\
\hline All & $160,276(64 \%)$ & $90,347(36 \%)$ & $250,623(100 \%)$ \\
\hline
\end{tabular}

Source: Adapted from GSS, 2012 PHC Report: 38

Finally, migrant women may also influence the societies of origin by disseminating new values about the rights and opportunities for women. The current trend where women are migrating independently means that they would also be paving the way for those back home to understand that women like men are also adventurers who can occupy and utilize public spaces. The migrant women can also return with new values that can help in reshaping if not their entire communities but those of their families and households with the potential of changing traditional gender roles. When men stay and women move, as

3 Includes North America, South America and the Carribean 
noted above, the shift in value has already happened but it is furthered when men have to take on roles traditionally considered male and when the women become independent migrants. The female migrants who are increasingly becoming part of the worker flows, moving on their own to become the principal wage earners for their families, also take on traditional male roles such as maintenance and providers. They also contribute to their families and communities in ways that break traditions and thus earn such women status and rewards not traditionally available for women.

\section{Women and Remittances}

Remittances, whether sent within or between countries, in cash or in-kind, are only part of the broader networks of engagement and solidarity between migrants and their homes. Migrants exchange knowledge, skills and information, and draw on extended social networks (HPG Report, 2007). Individual remittance transfers continue to be an important source of income for many families in developing countries. As a major alternative form of resources for not just individuals but also the social group, its effects on women and men are differentiated. As already demonstrated above, the processes, policies, processes, consequences and act of migration are already gendered. Hence, as an important outcome of migration, remittances are also gendered. Thus, a gender perspective is essential for understanding not just migration but also remittances. Women as the vulnerable and excluded of society naturally experience the gendering of social phenomena negatively. Hence, in this section the focus is on women as the vulnerable category.

As already noted above, gender inequality can be a powerful factor in precipitating migration when women have economic, political, and social expectations that opportunities at home do not meet.

Also, migration can be an empowering experience for women. In the process of international migration, women may move away from situations where they live under traditional, patriarchal authority to situations and destinations where they are empowered to exercise greater autonomy over their own lives. Also, those women who remain behind when their husbands or children migrate often have to take on new roles and assume responsibility for decisions affecting the socio-economic well-being of their households. Remittance becomes an important life-changing experience for such women.

Although not much is known about the differences in remitting behavior between migrant men and migrant women, some evidence suggests that migrant women remit more of their incomes to their families than migrant men, perhaps because of gender expectations regarding family contacts and filial obligations (Chant and Radcliffe, 1992; Curran and Saguy, 2001; Tacoli, 1999). The higher share of income that women remit appears to be the case for both international and internal migrants. A study on remitting behaviour in South Africa concluded that "employed migrant men are 25 per cent less likely than employed migrant women to remit" (Collinson et al, 2003). However, migrant women often earn less than their male counterparts' so the total revenue available for remittances 
may be lower. Studies on remitting behavior of internal migrants show that a woman's age and marital status are more important in determining whether she migrates or not.

Adepoju (2010:17-18) explains that:

Married women leave their spouses behind with the children, who, in a reversal of responsibilities, are looked after by their fathers, or by other female members of the family. The remittances these women send home are for a lifeline family sustenance. This phenomenon of independent female migration constitutes and important change, and clearly can imply a turn -around in traditional gender roles, again creating new challenges for public policy.

Clearly not only is female migration providing a lifeline of support, it also reverses and thus defies the traditional model of the private domesticated woman and public liberated man.

While ODA generally goes to Governments, which make decisions about its use, remittances go to families, including many women-headed households, who use the funds in the manner they believe most conducive to meeting their own needs. Not only does remittance become important for reducing poverty but also for leveraging wealth and social status. By providing additional income to poor households, remittance empowers the women who receive them to make decisions about their use (De Haan, 2000). For those women, whose husbands are in migration, it offers them the opportunity to make household decisions and allocate and use family resources. This will not be the case with the male head within the household.

Also, according to the Global Commission on International Migration (2005), it is also noteworthy that migrant women and lower-paid migrants at times transfer a higher proportion of their income than others do. Thus, special efforts should be made to target women in such initiatives. The discrimination that women face as independent but also dependent migrants in the receiving destinations are a matter of concern.

Furthermore, there is growing anecdotal evidence that women make better use of remittances than men. Women tend to spend more on family needs such as food, health, education and housing whereas men tend to spend money on personal needs, such as consumer goods, cars or alcohol. Hence, if remittance is to serve the purpose of an equalizer or balancer and especially for poverty reduction, then, we need to understand the ways in which women and men participate and are affected by migration.

\section{Engendering Migration and Remittance}

As migration and remittance have become big business, with states, communities and families cashing in on its benefits, the settlement of the gender challenge becomes even 
more imperative. The women and men trapped in the process and who suffer because of their decisions to seek better living conditions and opportunities elsewhere for improving themselves and their families, contribute significantly to their home economies through remittances. It thus behooves on the various agencies and actors to contribute their quotas toward the reduction of the myriad challenges that such migrants have to face.

\section{Streamlining Migration Policies}

Although progress has been made toward the improvement of migration policies and processes in order to encourage legal compared to illegal migration, a lot still remains to be done. The seeming lack of clarity opens the policies to diverse interpretations. As well, it creates conditions for the manipulation and exploitation of migrants. More so the diverse and changing nature of the policies create confusion and the tendency for border control officials to subject the policies to unintended uses. The policies that govern migration at the global, regional and country level need to be streamlined and made more accessible to all. For instance, citizens of the Economic Community of West African States ECOWAS), are entitled to cost and hustle free entry to one another's countries. However, border officials find ways to hold and delay commuters to the extent that it becomes a disincentive to exercise that right. Commuters will rather submit themselves to the extortions to stay out of trouble than to assert their rights. The delays also expose vulnerable groups such as women and girls to other forms injustices, some sexual in nature, which could undermine their human and citizen rights.

Migrants do not have to suffer unduly from the lack of clarity and information for potential migrants. This creates room for criminals and their gangs to take advantage of and exploit innocent migrants. At the border posts of almost all ECOWAS states one canfind so-called agents who offer themselves up to help fast track the document processing of travellers. National, regional and global policies need to be aligned and made accessible in various forms and media for quick and easy access. But above all, when there is information on and clarity of policy, efforts should be put in place to ensure that border officials and other facilitators do not trample of the rights of migrants. The lack of enforcement of policies is often a major challenge for migrants.

There is the need for governments to increase and manage migration, reduce transfer costs, formalize remittance flows, link remittances to micro-finance strategies, and mobilize migrant organizations. The involvement of the international community in the remittance business is justified by calling for more research on the migration, remittances and development nexus will bring about better policies to increase the positive impacts of remittances. An understanding of the nexus and how gender play out should encourage governments and international community to develop strategies that can benefit

remittance senders and receivers, and thereby automatically increase the poverty reduction impact of remittances (local and international). 


\section{Mainstreaming Immigration Agencies}

The Ghana Immigration Service, Customs and Excise Department and border security agencies such as the Police and Ghana Ports and Harbors Authority, are important agencies for not only facilitating legal migration but also important sources for gathering data on migration and remittances as well as for supporting migrants. While the immigration agencies are mandated to protect the national borders from illegal migrants and criminality, it is also important to recognize that many migrants will not use illegal routes and methods if properly aided. For the many and diverse reasons that men and women migrate, it is necessary for immigration officials to understand and assist them in their professional capacities as public servants. Immigration officials need to understand and support the differentiated needs of the men and women who pass through their offices and posts on a daily basis and support them accordingly.

Apart from understanding the differential needs of the men and women they deal with, it is also important to put in measures to address those needs. These days, it is common to have women search women at the exit and entry points, and rightly so. However, it is even more important to understand that the ways men and women are searched could have differential effects when such searches are conducted in the open and in the glare of all. It is very embarrassing and invasive for women, more than men, travelers when they are subjected to searches that involve the touching of breasts, buttocks and even vagina area, for instance. Such searches could be done with some form of decency and technology, especially when there are machines to do such searches. Border officials need to be regulated on the type and extent of search they can conduct in the open and how to handle travelers. Many times there are duplications or confusion of roles among the various agencies leaving migrants, potential or actual, in the middle groping for solutions. Sometimes, it is just the lack of knowledge and skills on the part of the officials for supporting migrants with information and guidance. Other times the agencies are so wide apart that time is wasted trying to get information or documents processed. Whatever the case may be a streamlining of policies and programme should seek to clarify roles and eliminate the hustle, especially so for women.

\section{Disaggregating Migration and Remittances Data}

A better understanding of women and migration requires improvements in data collection, dissemination, and analysis. Migrant women play a part in the economic development of both their countries of destination and their countries of origin through financial contributions in the form remittances, the improvement of their own skills or their contributions to the improvement of the education and skills of the next generation. Statistics on international migration, both legal and unauthorized, are far from reaching universal coverage and are often published without classification by sex or age (Global Commission on International Migration, 2005). Disaggregated data is useful for tracking and supporting the trends in order to ensure that both women and men migrants' needs and challenges are addressed. 


\section{Improving Gender Research and Documentation}

For our Ghanaian context, there is a paucity of research and documentation on remittance and migration flows and their gender dimensions. While there is significant information, in recent years, on migration trends including the gender aspects, the regional dimensions remain and their connections to remittances remain weak. Although some studies exist on the gender aspects of remittances and migration, especially for Africa and Ghana, many such studies are anecdotal and tend to lack the robust data and rigorous analysis for policy making and programming support. There are also those studies that treat gender or women as appendage es in a male-dominated enterprise. In many cases, a small aspect of the analysis and report is devoted to female migration, gender and migration or women's migration. However, with the growing involvement and expanding roles of women in migration, there is the need for more and better evidence. There is the need for research data that provide the statistics but also shed light on women's experiences as distinct from men. We need data to verify the anecdotal evidence but we also need depth in the experiences shared, often as snippets. These should help build a broad gender picture and help guide policy and advocacy on migration reforms that are gender sensitive.

There is often the stereotyping of women in migration and especially so for young women who migrate independently. Many are often tagged prostitutes and deviants. Yet for many such women all they have sought is better opportunities to fulfill themselves and actualize their potentials. Stereotypes can have powerful implications for the concrete lives of women and men. Some stereotypes can have positive outcomes, and can be useful from activists points of view. However, stereotyping often has detrimental effects, or negative long-term implications (See ISA Convention, 2006). Research and documentation would help close the knowledge gaps.

A related important issue for research is the need to analyze the links between migration, remittances, and development. Hopefully, this will help render visible the social dynamics in which the issue of remittances is embedded such as gender, class and ethnicity. Even though there exists gender stereotyping about remittances these have tended to position 'women are mainly remittance receivers' when indeed there is evidence that women are remittance senders and that when they do, they send more remittances than men do.

\section{Conclusion}

Undoubtedly, migration has come to stay as an important enterprise for both sending and receiving countries and regions. It generates resources for both senders and receivers. However, in the case of sending countries, remittances have become a major source of aid to families, communities and nations, and estimated to compare with official development aid in recent time. The men and women who participate in migration do so for diverse reasons however the urgency of remittances remains the same. The changes in the reasons for migrating are showing new trends where female migration is on the rise. Women, like men, have always migrated for economic, educational and social reasons. 
No matter the reason, remittance is expected and especially in the case of Ghana, where social tides are strong and attended with financial expectations. However, discriminatory migration policies and practices as well as negative socio-cultural values have tended to construct migration as a male terrain with women as appendages who are stereotyped in various ways including as receipts and dependents. Women also tend to be vulnerable to various forms of exploitation. In these changing times, when women are increasingly participating as independent migrants, whose remittances contribute to support families and communities back home, there is the greater imperative to rethink migration policies and practices. The emerging feminizing trend gives cause for examining migration policies and practices and especially for applying a gender lens to them by improving research and documentation, disaggregating data by sex and streamlining the agencies responsible for migration.

\section{References}

Abdellatif, Ben Hadj (2010). African Skilled Labour Migration: Dimensions and Impact. In Adepoju, Aderanti (ed.). International Migration within, to and from Africa in a Globalized World. (97-136) Accra, Ghana: Sub-Saharan Publishers

Adepoju, Aderanti (2010). Introduction: Rethinking the Dynamics of Migration within, from and to Africa. In Adepoju, Aderanti (ed.). International Migration within, to and from Africa in a Globalized World. (9 - 45) Accra, Ghana: Sub-Saharan Publishers

Adepoju, Aderanti (2005). Patterns of Migration in West Africa. In Manuh, Takyiwaa(ed.). At Home in the World? International Migration and Development in Contemporary Ghana and West Africa. (24 - 54). Accra, Ghana: IAS, UG/UNDP/Sub-Saharan Publishers

Anarfi, John, K.; Kwankye, Stephen O. and Clement Ahiadeke (2005). Migration, Return and Impact in Ghana: A Comparative Study of Skilled and Unskilled Transnational Migrants. In Manuh, Takyiwaa(ed.). At Home in the World? International Migration and Development in Contemporary Ghana and West Africa. (204-226). Accra, Ghana: IAS, UG/UNDP/Sub-Saharan Publishers

Asante, Y. (1995). "Migration-Development Interrelationships." Twum-Baah, K.A.; Nabila, J. S. \& A. F. Aryee (eds.)." In Migration Research Study in Ghana. Accra: Ghana Statistical Service.

Apusigah, Agnes Atia and Adama-Mohammed, Janet (2005). "Baseline Study on Human Trafficking and Forced Labour in Ghana." Accra, GH: International Labour Organization (July).

Barclay, Anthony (2010). Regional Economic Commissions and Intra-Regional Migration Potential in Africa: Taking Stock. In Adepoju, Aderanti (ed.). International Migration 
within, to and from Africa in a Globalized World. (46 - 96) Accra, Ghana: Sub-Saharan Publishers

Bos-Jones, Renee (2005). The Dutch Perspective on Contemporary Migration. In Manuh, Takyiwaa(ed.). At Home in the World? International Migration and Development in Contemporary Ghana and West Africa. (103-117). Accra, Ghana: IAS, UG/UNDP/ SubSaharan Publishers

Boakye-Yiadom, L. (2008). 'Rural-Urban Linkages and Welfare: The Case of Ghana's Migration and Remittance Flows', A thesis submitted for the degree of Doctor of Philosophy. University of Bath.

Bjeren, G. (1997). "Gender and reproduction," in T. Hammar et al. (eds.) International Migration, Immobility and Development, New York: Berg, pp. 219-246.

Carling, J. (2002). 'Migration in the age of involuntary immobility: Theoretical reflections and Cape Verdean experiences.' Journal of Ethnic and Migration Studies, 28(1):5-42.

Carling, J. (2005). 'Gender Dimensions of International Migration,' Journal of Ethnic and Migration Studies, 11(3):399-401.

Chant, S. and Radcliffe, S. A. (1992). Development and Migration: Importance of gender. In Chant, S. (ed.). Gender Migration in Developing Countries. Belhaven Press: London

Curran, S.R. \& Saguy, A.C. (2001). "Migration and cultural Change: A role for gender and social networks”, Journal of International Women's Studies, 2(3): 54-77.

De Haan, A., (2000). 'Migrants, Livelihoods and Rights: The Relevance of Migration in Development Policies.' Social Development Working Paper No 4, London: Department for International Development.

Gyimah-Brempong, K., and Asiedu, E. (2009). 'Remittances and Poverty in Ghana' Paper to be presented at the 4th African Economic Conference (AEC), Addis Ababa, Ethiopia, November 2009.

Global Commission on International Migration (2005). 'Report of a Workshop on Gender Dimensions of International Migration’, GCIM, 23-24 March

Ghana Statistical Service (GSS)(2000). Poverty Trends in Ghana in the 1990s. Accra, Ghana, October 2000.

Hashim, I. M. (2005). 'Independent Child Migration in Ghana: A Research Report', Brighton: Development Research Centre on Migration, Globalization and Poverty, University of Sussex

Lee, E. S. (1966). “A Theory of Migration”, Demography, Vol.3, No.1, pp.47-57 
Manuh, Takyiwaa and Richard Asante (2005). Reaping the Gains of Ghanaians Overseas: An Evaluation of the Home Coming Summit. In Manuh, Takyiwaa(ed.). At Home in the World? International Migration and Development in Contemporary Ghana and West Africa. (277-291). Accra, Ghana: IAS, UG/UNDP/Sub-Saharan Publishers

Manuh, Takyiwaa; Asante, Richard and Jerome Djangmah (2005). The Brain Drain in Higher Education Sector in Ghana. In Manuh, Takyiwaa(ed.). At Home in the World? International Migration and Development in Contemporary Ghana and West Africa. (250 - 276). Accra, Ghana: IAS, UG/UNDP/Sub-Saharan Publishers

Oucho, John 0 (2010). African Diaspora and Remittance Flows: Leveraging Poverty? In Adepoju, Aderanti (ed.). International Migration within, to and from Africa in a Globalized World. (137-168) Accra, Ghana: Sub-Saharan Publishers

Quartey, P. (2006). "The impact of migrant remittances on household welfare in Ghana." AERC Research Paper 158 African Economic Research Consortium, Nairobi Kenya.

Ratha D. (2005). 'Workers Remittances: An Important and Stable Source of External Development Finance', In S. M. Maimbo and D. Ratha (eds.), Remittances: Development Impact and Future Prospects. Washington DC: World Bank.

Ratha D. (2010). Remittances to Africa's Resilience, despite the global financial crises. (A World Bank Study). Washington DC: The World Bank.

Savage, K. and Harvey, P. (2007). Remittances during crises: Implications for humanitarian response. HPG Briefing Paper 26. May 2007

Stølen, K. A. (1991). 'Introduction: Women, gender and social change', in Stølen, K. A. and Vaa, M. (eds.) Gender and change in developing countries.

Tacoli, C. (1999). 'International Migration and the Restructuring of Gender Asymmetries: Continuity and Change among Filipino Labor Migrants in

Rome', International Migration Review, 33(3):658-682.

Tienda, M. and Booth, K. (1991). Gender, Migration and Social Change. International Sociology, 6(1):51-72.

Twum-Baah, Kwaku (2005). Volume and Characteristics of International Ghanaian Migration. In Manuh, Takyiwaa(ed.). At Home in the World? International Migration and Development in Contemporary Ghana and West Africa. (55-77). Accra, Ghana: IAS, UG/UNDP/Sub-Saharan Publishers

World Bank (2004). “Global Development Finance. Washington DC: World Bank.

World Bank (2011). Migration and Remittance Factbook. The World Bank, Washington DC. 